\title{
PRELIMINARY INVESTIGATION OF MYO-INOSITOL PHOSPHATES PRODUCED BY ASUIA279PHYTASE ON MCF-7 CANCER CELLS
}

\author{
N.MOHD. YUSOFF ${ }^{1}$, T. NUGE ${ }^{1}$, N.H. ZAINAN ${ }^{1}$, Y.Z.H-Y. HASHIM ${ }^{1}$, \\ P. JAMAL ${ }^{1}$, ANIS Shobirin MeOR HUSSIN ${ }^{2}$, ABd-ElAzIEM FAROUK ${ }^{3}$ \\ AND H.M. SALLEH ${ }^{1}$ \\ ${ }^{I}$ Bioprocess and Molecular Engineering Research Unit, \\ Department of Biotechnology Engineering, International Islamic University Malaysia, \\ Jalan Gombak, 53100 Kuala Lumpur, Malaysia. \\ ${ }^{2}$ Department of Food Technology, Faculty of Science and Food Technology, 43400, \\ University Putra Malaysia, Serdang, Selangor, Malaysia. \\ ${ }^{3}$ Department of Biotechnology, Faculty of Science, Taif University, 21974 Taif, \\ Al-Hawiayah, P. O. Box. 888, Saudi Arabia. \\ hamzah@iium.edu.my; yumi@iium.edu.my
}

\begin{abstract}
Phytate or myo-inositol hexakisphosphates $\left(\mathrm{IP}_{6}\right)$ is widely distributed in plants like rice bran. The production of myo-inositol phosphate intermediates has received much attention due to the remarkable potential health benefits offered by the compounds. In this study, the cytotoxicity of the partially purified myo-inositol phosphate fractions and commercial $\mathrm{IP}_{1}$ and $\mathrm{IP}_{6}$ were investigated against MCF-7 breast cancer cell lines. The study showed that the commercial standard $\mathrm{IP}_{1}$ and $\mathrm{IP}_{6}$ showed good inhibition towards the MCF-7 cell line. The MCF-7 cells growth was inhibited in minimum concentration of myo-inositol phosphates $(<1000 \mu \mathrm{g} / \mathrm{ml})$. However, no inhibition observed on the MCF-7 cell line by the myo-inositol phosphates fractions partially purified from rice bran at concentration $<1000 \mu \mathrm{g} / \mathrm{ml}$. The inhibition of MCF-7 was only observed at concentration more than $30 \mathrm{mg} / \mathrm{ml}$ with more than $40 \%$ cells were inhibited. This indicates that the partially purified rice bran myo-inositol phosphates degraded by ASUIA279 phytase on MCF-7 breast cancer cells exhibit positive results towards the inhibition of cancer cells growth at relatively high concentration.
\end{abstract}

ABSTRAK: Fitat atau myo-inositol hexakisphosphate (IP6) dikenali umum teragih di dalam tumbuhan seperti dedak padi. Penghasilan perantaraan fosfat myo-inositol mendapat perhatian memandangkan ia berpotensi tinggi dalam kesihatan. Dalam kajian ini, kesitotoksikan sebahagian daripada fosfat myo-inositol separa tulen, IP1 komersil dan IP6 komersil dikaji terhadap produk yang berupa sel kekal (cell lines) kanser payu dara MCF-7. Tumbesaran sel MCF-7 direncatkan dalam pekatan minima fosfat myoinositol $(<1000 \mu \mathrm{g} / \mathrm{ml})$. Tetapi, tidak ada perencatan dilihat terhadap sel kekal MCF-7 oleh sebahagian fosfat myo-inositol separa tulen daripada dedak padi pada kepekatan $<1000 \mathrm{mg} / \mathrm{ml}$. Perencatan MCF-7 hanya dilihat pada kepekatan lebih daripada $30 \mathrm{mg} / \mathrm{ml}$ dengan lebih daripada $40 \%$ sel terencat. Ini menunjukkan bahawa fosfat myo-inositol daripada dedak padi separa tulen terdegradasi oleh fitat ASUIA279 terhadap sel kanser MCF-7 dimana ia menunjukkan keputusan positif terhadap perencatan tumbesaran sel kanser pada kepekatan tinggi.

KEYWORDS:myo-inositol phosphates; phytase; MCF-7cell line; cancer 


\section{INTRODUCTION}

Phytate or myo-inositol hexakisphosphates $\left(\mathrm{IP}_{6}\right)$ is widely distributed in plants, particularly in cereals and legumes, such as corn, soybean, wheat bran, rice bran, cotton seeds, rape seeds and soybean with a concentration range between $0.4 \%$ to $6.4 \%(\mathrm{w} / \mathrm{w})$ and also in mammalian cells at concentrations of $10 \mu \mathrm{M}$ to $1 \mathrm{mM}$ [1]. Phytase (myoinositol hexakisphosphate phosphohydrolase) is a phosphomonoesterase that acts on phytate in sequential and stepwise manner, releasing inorganic orthophosphate (Pi) and yielding partially phosphorylated myo-inositol phosphates which may again become substrates for further hydrolysis (Fig. 1) [2]. It catalyzes the degradation of phytic acid into lower myo-inositol phosphates; pentakis- $\left(\mathrm{IP}_{5}\right)$, tetrakis- $\left(\mathrm{IP}_{4}\right)$, tris- $\left(\mathrm{IP}_{3}\right)$, bis- $\left(\mathrm{IP}_{2}\right)$, and mono phosphate/s $\left(\mathrm{IP}_{1}\right)$; with the release of inorganic orthophosphate $(\mathrm{Pi})$ in sequential manner [3]. Phytases are found naturally in plants and microorganisms, particularly fungi [4].

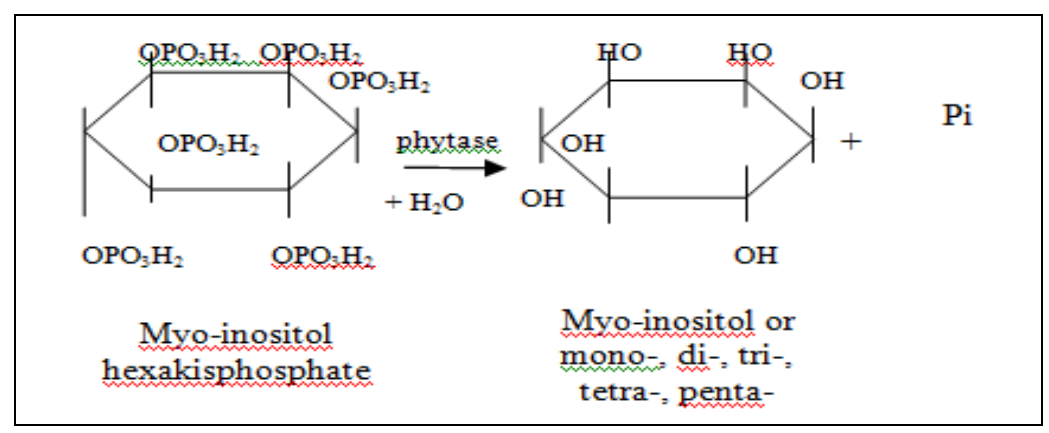

Fig. 1: Dephosphorylation of myo-inositol hexakisphosphate (phytate) by phytase.

Rice bran, the brown part of rice kernel, is a by-product of rice milling process, composed of seed coat, the major part of the germ, and most of the outer layer of the kernel together with some broken kernels [5]. Due to highly nutritious content of fat, protein and vitamins, it has been used as animal feed in most part of the world. The bran constitutes about $8.5 \%$ of the whole grain [6]. Current research interest is focused in utilizing this rice bran in many areas such as food, environmental, health and industrial purposes. In addition, rice bran also has been used as fermentation substrate for the production of enzymes such as lipase by Candida sp. [7], in combination with cassava starch and rice hulls for the production of glucoamylase by Aspergillus sp. [8], with wheat bran for the production of alkaline protease by Trichoderma koningii [9] and also for the production of protease from Rhizopus sp. [10].

The production of myo-inositol phosphate intermediates has received much attention due to the remarkable potential health benefits offered by the compounds [11]. Myoinositol phosphates have potential applications in many fields including pharmaceutical research and development. Myo-inositol $(1,3,4,5,6)$ pentakisphosphate has an antiangiogenic and antitumour effects which are useful for anticancer therapeutic strategies [12]. Some myo-inositol phosphates, including phytate, are present as intracellular molecules [13]. In addition, the second messenger D-myo-inositol $(1,4,5)$ trisphosphate has a range of cellular functions including secretion, contraction, cell division, cell differentiation and cell death cell via mobilizing intracellular $\mathrm{Ca}^{2+}[13]$. Meanwhile, it is believed that D-myo-inositol $(1,2,6)$ trisphosphate can prevent diabetes complications and treat chronic inflammations besides cardiovascular diseases [14]. Furthermore, a study showed that a combination of inositol hexakisphosphate $\left(\mathrm{IP}_{6}\right)$ and 
inositol gave better inhibition in different cancers such as in soft tissue, colon, metastaticlung, and mammary cancers than was either one alone [15]. In this present work, anion-exchange chromatography was used to partially separate myo-inositol phosphates from the reaction mixturecontaining rice bran and ASUIA279 phytase. The partially purified myo-inositol phosphates were then subjected to a cytotoxicity test on MCF-7 cells.

\section{MATERIALS AND METHOD}

\subsection{Production of ASUIA279 Phytase}

The cells of ASUIA279 [16] were grown in rice bran with distilled water under aseptic condition $\left(\mathrm{pH} 7,37^{\circ} \mathrm{C}, 250 \mathrm{rpm}, 60\right.$ hour incubation time). Samples were withdrawn at time intervals, centrifuged at $12,000 \mathrm{rpm}$ for $30 \mathrm{~min}, 16^{\circ} \mathrm{C}$ to remove the particulates and the supernatant kept at $-20^{\circ} \mathrm{C}$ for further analysis. Twenty milliliters of aliquot were collected and kept at $-20^{\circ} \mathrm{C}$ for storage.

\subsection{Phytase Assay}

Phytase assay was performed according to [17] with minor modifications to measure the enzyme activity of phytase produced. It was measured in a mixture of $25 \mu \mathrm{l}$ of $0.1 \mathrm{M}$ sodium acetate buffer, $\mathrm{pH} 4.5$ and $10 \mu \mathrm{l} 1.03 \mathrm{mM}$ sodium phytate in $200 \mu \mathrm{L}$ microcentrifuge tube. Enzyme $(5 \mu \mathrm{l})$ was added to the mixtures to initiate reaction. The mixtures of the enzyme and buffer was incubated for $30 \mathrm{~min}$ at $50^{\circ} \mathrm{C}$ in block heater (SHT 100D, Stuart Scientific). The released phosphate was quantified by ammonium molybdate method [18]. Stop solution $(150 \mu \mathrm{l})$ consists of acetone / $5 \mathrm{~N}$ sulphuric acid / ammonium molybdate $(2: 1: 1)$ was added to the assay mixture followed by $10 \mu 11.0 \mathrm{M}$ citric acid. Any cloudiness was removed by centrifugation (MiniSpin ${ }^{\circledR}$, Eppendorf) at room temperature, 10, $000 \mathrm{rpm}$ for 10 min prior to spectrophotometric measurement at $355 \mathrm{~nm}$ by micro plate reader, Infinite ${ }^{\circledR} 200$ Pro series (TECAN Group Ltd.). The phytase activity was expressed as 1 micromol of phosphate liberated per min (Equation 3.1). ( $\varepsilon$ microplate $=0.3094 \mu / \mathrm{M} . \mathrm{cm} ; \mathrm{d}_{\text {depth of microplate for } 200 \mu \mathrm{l} \text { solution }}=0.59 \mathrm{~cm} ; t=$ incubation time $(\mathrm{min}) ; \mathrm{Abs}_{355}=$ Absorbance at $355 \mathrm{~nm} ; \mathrm{V}_{\text {total }}=$ total volume of assay solution; $\mathrm{V}_{\text {enzyme }}=$ volume of enzyme used).

$$
\text { Activity }=\frac{A b s 355 \times V_{\text {total }}}{d \times \mathcal{E} \times t \times V_{\text {enzyme }}}
$$

\subsection{Extraction of Myo-inositol Phosphates}

Rice bran (donated by BERNAS Tanjung Karang, Selangor Darul Ehsan) was used as a fermentation media for the production of bacterial phytase from local isolates, ASUIA279. The cell culture broth of ASUIA279 was grown in the presence of $10 \% \mathrm{w} / \mathrm{v}$ rice bran with distilled water under aseptic condition and $\mathrm{pH} 7,37^{\circ} \mathrm{C}$ and $250 \mathrm{rpm}$. Samples withdrawn from 0 hour until 72 hours were then centrifuged at 12,000 rpm for 30 min to remove particulates and the supernatant kept at $-20^{\circ} \mathrm{C}$ for further analysis.

\subsection{Separation and Recovery of myo-inositol Phosphates}

AG1 X-4 (100-200 mesh) (BioRad Laboratories, USA) anion exchanger resin was packed in a glass column $(2.5 \times 30 \mathrm{~cm})$ and equilibrated with distilled water. About $15 \mathrm{ml}$ of the supernatant was loaded on to the column. Three concentrations of hydrochloric acid (Merck, Germany) were used to elute the sample in a stepwise gradient; $0.1 \mathrm{M}, 0.5 \mathrm{M}, 1.0$ 
M. All collected samples were kept at $4^{\circ} \mathrm{C}$. Following thawing, solvent was removed by a rotary evaporator. The dried samples were diluted with a small amount of distilled water and further concentrated by a spin-concentrator. The completely dried residue (partially purified myo-inositol phosphate) was kept in a desiccator to avoid any reintroduction of moisture. The percentage yield of myo-inositol phosphates and myo-inositol phosphate intermediates eluted by three different concentration of $\mathrm{HCl}$ from ASUIA279were determined.

$$
\begin{aligned}
\text { yield }(\%) & =\frac{w 2-w 1}{w 1} \times 100 \\
\mathrm{w} 1 & =\text { weight of centrifuge tube } \\
\mathrm{w} 2 & =\text { weight of centrifuge tube and dried sample }
\end{aligned}
$$

\subsection{Effects of Myo-inositol Phosphates on MCF-7 Breast Cancer Cell Line}

\subsubsection{Preparation of Standards and Samples for MCF-7 Tests}

Six standard samples of myo-inositol phosphates were used as reference during the investigation (Table 1). The standards were diluted in $1 \mathrm{ml}$ of $10 \%$ DMSO.

Table 1: Amount of myo-inositol phosphates standards used.

\begin{tabular}{|c|c|c|}
\hline Standard & $\begin{array}{c}\text { Concentration (Stock } \\
\text { solution) }(\mathbf{g} / \mathbf{m l})\end{array}$ & $\begin{array}{c}\text { Concentration (Dilution) } \\
(\mu \mathbf{g} / \mathbf{m l})\end{array}$ \\
\hline $\mathrm{IP}_{1}$ & 0.05 & 1000 \\
\hline $\mathrm{IP}_{2}$ & 0.0005 & 100 \\
\hline $\mathrm{IP}_{3}$ & 0.0025 & 500 \\
\hline $\mathrm{IP}_{4}$ & $5 \times 10^{-5}$ & 10 \\
\hline $\mathrm{IP}_{5}$ & $2.5 \times 10^{-4}$ & 50 \\
\hline $\mathrm{IP}_{6}$ & 0.125 & 1000 \\
\hline
\end{tabular}

A small quantity of partially purified myo-inositol phosphates were dissolved in $1 \mathrm{ml}$ of $10 \%$ DMSO to a maximum concentration (Table 2). MCF-7 cells were cultured in Dulbecco Modified Eagle Medium (DMEM) supplemented with $10 \%$ fetal bovine serum and the cell lines were maintained at $37^{\circ} \mathrm{C}$ in a $5 \% \mathrm{CO}_{2}$ incubator and the media were changed twice weekly.

\subsubsection{Cancer Inhibition Assay: Sulforhodamine B (SRB) Assay}

The SRB assay was performed to assess growth inhibition based on colorimetric principles. This assay estimates cell number indirectly by staining total cellular protein with SRB dye. Briefly, $190 \mu \mathrm{l} /$ well of cell suspensions (seeding density of $2.0 \times 10^{4}$ cells per well) and $10 \mu \mathrm{l} /$ well myo-inositol phosphates of different concentrations $(31.25 \mu \mathrm{g} / \mathrm{ml}$ to $1000 \mu \mathrm{g} / \mathrm{ml}$ prepared in DMSO, Table 2) were seeded in 96-well microtiter plate. The 96-well plate was then incubated for 72 hours at $37^{\circ} \mathrm{C}$ and $5 \% \mathrm{CO}_{2}$, to allow for cell attachment. Without removing the cell culture supernatant, the cells were fixed with 100 $\mu \mathrm{l}$ of $10 \%(\mathrm{w} / \mathrm{v})$ trichloroacetic acid at $4^{\circ} \mathrm{C}$ for 1 hour and the supernatant was removed from the 96 well plates. The plate was then washed four times with slow running tap water 
Mohd. Yusoff et al.

and excess water was removed using a blow dryer or just allowed to stand at room temperature. Each well was stained for 30 min with $100 \mu \mathrm{l}$ of $0.4 \%$ (w/v) SRB dissolved in $1 \%$ acetic acid and washed four times with $1 \%$ acetic acid. The protein bound dye was solubilized with $200 \mu \mathrm{l}$ of $10 \mathrm{mmol} / \mathrm{l}$ Tris base, $\mathrm{pH} \mathrm{10.5}$. The absorbance (OD) of each well was read on an ELISA plate reader at $510 \mathrm{~nm}$. Percentage of control cell growth was calculated using the formula: \% of cell growth $=$ [mean OD sample/mean OD negative control]. A dose response curve was then plotted. Negative control $=10 \%$ DMSO.

Table 2: Concentration of myo-inositol phosphates in DMSO.

\begin{tabular}{|c|c|c|c|}
\hline $\begin{array}{l}\text { Sample aliquot } \\
\text { (hour) }\end{array}$ & $\begin{array}{c}\text { Eluent }(\mathbf{H C l}) \\
\text { concentration } \\
(\text { Molar, M) }\end{array}$ & $\begin{array}{l}\text { Weight of myo- } \\
\text { inositol } \\
\text { phosphates }(\mu \mathrm{g})\end{array}$ & $\begin{array}{c}\text { Concentration of myo- } \\
\text { inositol phosphates in } \\
1 \mathrm{ml} 10 \% \text { DMSO } \\
(\mu \mathrm{g} / \mathrm{ml})\end{array}$ \\
\hline \multirow{3}{*}{$\begin{array}{c}\text { Before } \\
\text { inoculation }\end{array}$} & 0.1 & 2500 & 2500 \\
\hline & 0.5 & 4000 & 4000 \\
\hline & 1.0 & 2800 & 2800 \\
\hline \multirow[t]{3}{*}{0} & 0.1 & 6100 & 6100 \\
\hline & 0.5 & 4600 & 4600 \\
\hline & 1.0 & 2600 & 2600 \\
\hline \multirow[t]{3}{*}{16} & 0.1 & 5800 & 5800 \\
\hline & 0.5 & 40300 & 40300 \\
\hline & 1.0 & 66800 & 66800 \\
\hline \multirow[t]{3}{*}{24} & 0.1 & 24400 & 24400 \\
\hline & 0.5 & 7700 & 7700 \\
\hline & 1.0 & 3900 & 3900 \\
\hline \multirow[t]{3}{*}{40} & 0.1 & 13000 & 13000 \\
\hline & 0.5 & 5700 & 5700 \\
\hline & 1.0 & 5500 & 5500 \\
\hline \multirow[t]{3}{*}{48} & 0.1 & 18300 & 18300 \\
\hline & 0.5 & 5000 & 5000 \\
\hline & 1.0 & 2300 & 2300 \\
\hline \multirow[t]{3}{*}{64} & 0.1 & 14300 & 14300 \\
\hline & 0.5 & 1500 & 1500 \\
\hline & 1.0 & 4400 & 4400 \\
\hline \multirow[t]{3}{*}{72} & 0.1 & 5600 & 5600 \\
\hline & 0.5 & 9400 & 9400 \\
\hline & 1.0 & 2500 & 2500 \\
\hline
\end{tabular}




\section{RESULTS AND DISCUSSION}

\subsection{Analysis of Myo-inositol Phosphate Obtained}

Three different concentration of eluent: $0.1 \mathrm{M}, 0.5 \mathrm{M}$ and $1.0 \mathrm{M} \mathrm{HCl}$ (Table 3) were used to elute the myo-inositol phosphates from AG1 X-4 resins. Further, ASUIA279 was incubated and monitored for 72 hours. The highest yield of myo-inositol phosphates obtained is at 16 hours incubation time (Fig.2) and then it started to decrease by time. It is known that during enzymatic phytate degradation, the hydrolysis rate decreased markedly [19]. This might be due to product inhibition by phosphate or a lower hydrolysis rate of the lower phosphate esters of myo-inositol. Another factor is because of the conditions used during the hydrolysis reaction [20]. A very slow degradation also had been observed by Van der Kaay and Van Haastert [21] which is during degradation of myo-inositol trisphosphate intermediate and the missing capability to degrade the myo-inositol bisphosphate intermediate.

Table 3: Percentage yield of myo-inositol phosphates and intermediates eluted by three different concentration of $\mathrm{HCl}$ from ASUIA279.

\begin{tabular}{|c|c|c|c|}
\hline $\begin{array}{l}\text { Sample aliquot } \\
\text { (hour) }\end{array}$ & Eluent $(\mathrm{HCl}$ in $\mathrm{M})$ & $\begin{array}{l}\text { Weight of myo-inositol and } \\
\text { its intermediates }(\mu \mathrm{g})\end{array}$ & $\begin{array}{c}\text { Yield } \\
(\%)\end{array}$ \\
\hline \multirow{3}{*}{$\begin{array}{l}\text { Before inoculation } \\
\text { (control) }\end{array}$} & 0.1 & 0.0811 & 7.68 \\
\hline & 0.5 & 0.0495 & 4.69 \\
\hline & 1.0 & 0.045 & 4.26 \\
\hline \multirow[t]{3}{*}{0} & 0.1 & 0.1126 & 10.67 \\
\hline & 0.5 & 0.049 & 4.64 \\
\hline & 1.0 & 0.0516 & 4.89 \\
\hline \multirow[t]{3}{*}{16} & 0.1 & 0.0788 & 7.47 \\
\hline & 0.5 & 0.2009 & 19.03 \\
\hline & 1.0 & 0.02991 & 28.34 \\
\hline \multirow[t]{3}{*}{24} & 0.1 & 0.0681 & 6.45 \\
\hline & 0.5 & 0.0188 & 1.78 \\
\hline & 1.0 & 0.0111 & 1.056 \\
\hline \multirow[t]{3}{*}{40} & 0.1 & 0.1046 & 9.91 \\
\hline & 0.5 & n.a* & n.a* \\
\hline & 1.0 & 0.0521 & 4.94 \\
\hline \multirow[t]{3}{*}{48} & 0.1 & 0.0785 & 7.44 \\
\hline & 0.5 & 0.0441 & 4.18 \\
\hline & 1.0 & 0.0047 & 0.45 \\
\hline \multirow[t]{3}{*}{64} & 0.1 & 0.1291 & 12.23 \\
\hline & 0.5 & 0.0435 & 4.12 \\
\hline & 1.0 & 0.0414 & 3.92 \\
\hline \multirow[t]{3}{*}{72} & 0.1 & 0.0546 & 5.17 \\
\hline & 0.5 & 0.149 & 14.17 \\
\hline & 1.0 & 0.0438 & 4.15 \\
\hline
\end{tabular}




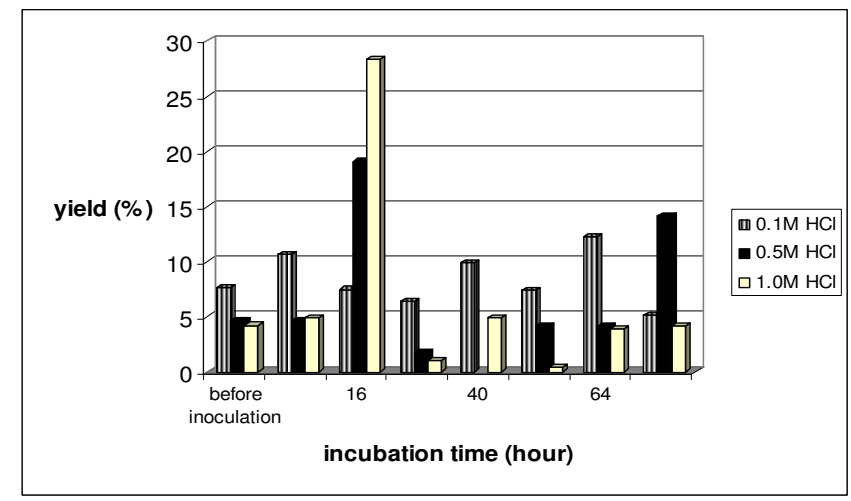

Fig. 2: Fraction of myo-inositol phosphate intermediates separated by anion exchange chromatography from ASUIA279 by three different concentrations of $\mathrm{HCl}$.

Since lower myo-inositol phosphates have less negative charge compared to higher myo-inositol phosphates, the lower myo-inositol phosphates (e.g. $\mathrm{IP}_{1}, \mathrm{IP}_{2}, \mathrm{IP}_{3}$ ) will be eluted earlier and easily by low concentration of $\mathrm{HCl}$. Meanwhile, higher myo-inositol phosphates (e.g. $\mathrm{IP}_{4}, \mathrm{IP}_{5}, \mathrm{IP}_{6}$ ) will be eluted by higher concentration of $\mathrm{HCl}$. Moreover, the effective charges of myo-inositol phosphates (e.g. $\mathrm{IP}_{5}$ and $\mathrm{IP}_{6}$ ) will be decreased if the acidity of eluent is increasing, which proves the existence of ion suppression mechanism in eluent [22]. The higher the effective charge of the analyte, the longer the retention time of the IPs, and this is also applicable to the isomers. The fluctuated reading of the yield might be caused by the insufficient elution of the myo-inositol phosphates or weaker binding of the phytate to the anion exchanger resin [23].

\subsection{The Effects of Myo-inositol Phosphates to MCF-7 Breast Cancer Cell Line}

A novel anticancer function of inositol hexaphosphate $\left(\mathrm{IP}_{6}\right)$ has been shown both in vivo and in vitro [24]. Commonly, most research about inhibition of cancer cells growth were focused on $\mathrm{IP}_{6}$ and applied in various cell lines including human leukemia cells [25], human colon cancer cells [26], both estrogen receptor-positive and estrogen receptornegative human breast cancer cells [27], laryngeal carcinoma [28], cervical cancer [29], prostate cancer [30], hepatoma [31], pancreatic [32] and melanoma cell line [33].

Due to a limited amount of standards available, different concentration of sample was used. As can be observed from the experiment, multi well plate that contain $\mathrm{IP}_{6}$ and $\mathrm{IP}_{1}$ immediately change to yellow colour after exposure of cell to the solution containing myoinositol phosphates. In consequence, highest concentration of $\mathrm{IP}_{1}$ and $\mathrm{IP}_{6}$ showed good inhibition towards the MCF-7 cell line (Fig. 3). This showed that $\mathrm{IP}_{6}$ supported by Vucenik and Shamsuddin [15], and $\mathrm{IP}_{1}$ efficiently inhibit the cancer cell growth. Based on the observation, minimum concentration of myo-inositol phosphates $(<1000 \mu \mathrm{g} / \mathrm{ml})$ contributed minimum inhibition against the growth of MCF-7 cell line. 


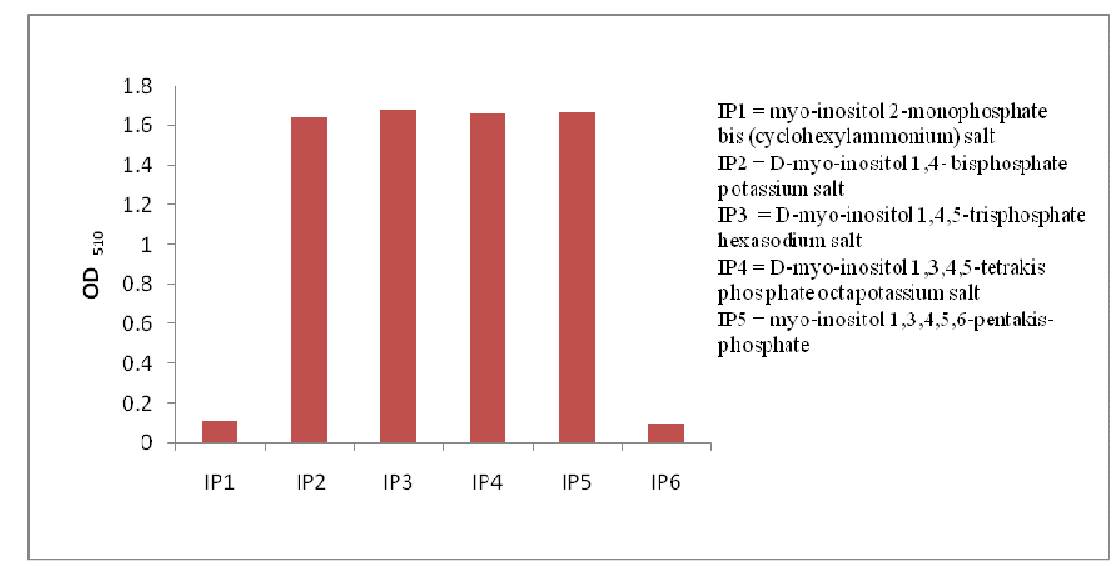

Fig. 3: Optical density of six standards of myo-inositol phosphates measured at $510 \mathrm{~nm}$.

The next step is to study the inhibition of partially purified myo-inositol phosphates extracted from rice bran towards the MCF-7 cell line. Table 2 listed the concentration of myo-inositol phosphates used in this study. Prior to that, a serial dilution of samples ranges from $62.5 \mu \mathrm{g} / \mathrm{ml}$ to $1000 \mu \mathrm{g} / \mathrm{ml}$ were applied to MCF-7 cell line. Nevertheless, no significant changes had been observed throughout the experiment. Once again, lower concentration $(<1000 \mu \mathrm{g} / \mathrm{ml})$ of partially purified myo-inositol phosphates were not capable to inhibit the growth of MCF-7 cell line. Since rice bran only has $4 \%$ of phytate content [34] compared to pure phytate, it is relevant if $1000 \mu \mathrm{g} / \mathrm{ml}$ was not efficiently inhibit the growth of MCF-7 cells as the standard of $\mathrm{IP}_{1}$ and $\mathrm{IP}_{6}$. Theoretically, in $1 \mathrm{ml}$ of sample, about 0.04 fractions were myo-inositol phosphates. The insufficient amount of myo-inositol phosphates used before, leads us to use larger amount of myo-inositol phosphates which diluted in 10\% DMSO (Table 2).

The SRB assay was then carried out and measured by microplate reader at $510 \mathrm{~nm}$. Figure 4 illustrated the percentage of growth for MCF-7 cells after applied by partially purified myo-inositol phosphates. The minimum amount of observed optical density indicated the inhibition of MCF-7 cells growth in the mixture. Two samples showed positive results supporting this conclusion. A decrement of growth had been observed for samples at 16 hour incubation time for $0.5 \mathrm{M}$ and $1.0 \mathrm{M}$ elution of $\mathrm{HCl}$ respectively. The highest concentration contained in both samples proved that the growth of MCF-7 cells really can inhibit by partially purified myo-inositol phosphates. According to statement by Adachi et al. [34], about $1.612 \mathrm{mg} / \mathrm{ml}$ and $2.672 \mathrm{mg} / \mathrm{ml}$ of phytates content in both samples, respectively. However, for samples containing less than $30 \mathrm{mg} / \mathrm{ml}$ of partially purified myo-inositol phosphates showed none or minimum inhibition of MCF-7 cells growth.

Moreover, throughout the analysis, more than $40 \%$ inhibition of MCF-7 cells had been observed by partially purified myo-inositol phosphates extracted from rice bran. About $44.6 \%$ and $46.6 \%$ of inhibitions had been calculated for both $0.5 \mathrm{M}$ and $1.0 \mathrm{M}$ elution of $\mathrm{HCl}$ at 16 hour incubation time of ASUIA279. Mostly, myo-inositol phosphates consist of $\mathrm{IP}_{3}, \mathrm{IP}_{4}, \mathrm{IP}_{5}$ and $\mathrm{IP}_{6}$ were in both samples and able to inhibit the MCF-7 cells growth. $\mathrm{IP}_{6}$ inhibited the growth of cancer cell lines in a dose- and time-dependent manner, irrespective of whether they were epithelial or mesenchymal in origin [35]. Moreover, the anticancer activity of $\mathrm{IP}_{6}$ is a result of its rapid intake by tumor cells was shown when MCF-7 human breast cancer cells were incubated with $\left[{ }^{3} \mathrm{H}\right]-\mathrm{IP}_{6}$. As early as 1 minute after incubation, $3.1 \%$ of $\mathrm{IP}_{6}$-associated radioactivity was taken up by MCF-7 cells 
and $9.5 \%$ after 1 hour. Anion-exchange chromatography showed that $58 \%$ of the absorbed radioactivity was in $\mathrm{IP}_{6}$ form, indicating that externally applied $\mathrm{IP}_{6}$ enters the cells followed by dephosphorylation. However, $\mathrm{IP}_{4}$ appeared to be a predominant metabolite of $\mathrm{IP}_{6}$, which possibly might have important role in its anticancer activity [35]. Shamsuddin and Vucenik [36] cited that $\mathrm{IP}_{6}$ also was used to enhance the anti-proliferative effects of tamoxifen and adriamycin to MCF-7 cells line.

As a whole, $\mathrm{IP}_{6}$ and its metabolites can differentially inhibit the proliferation of cancer cells without affecting the normal cells, inhibit cell proliferation of cancer cells irrespective of their hormonal receptor status and individual $\mathrm{IP}_{6}$ metabolite(s) or combinations could be specifically effective against specific cancers, thereby increasing the chances of successful therapy [34].

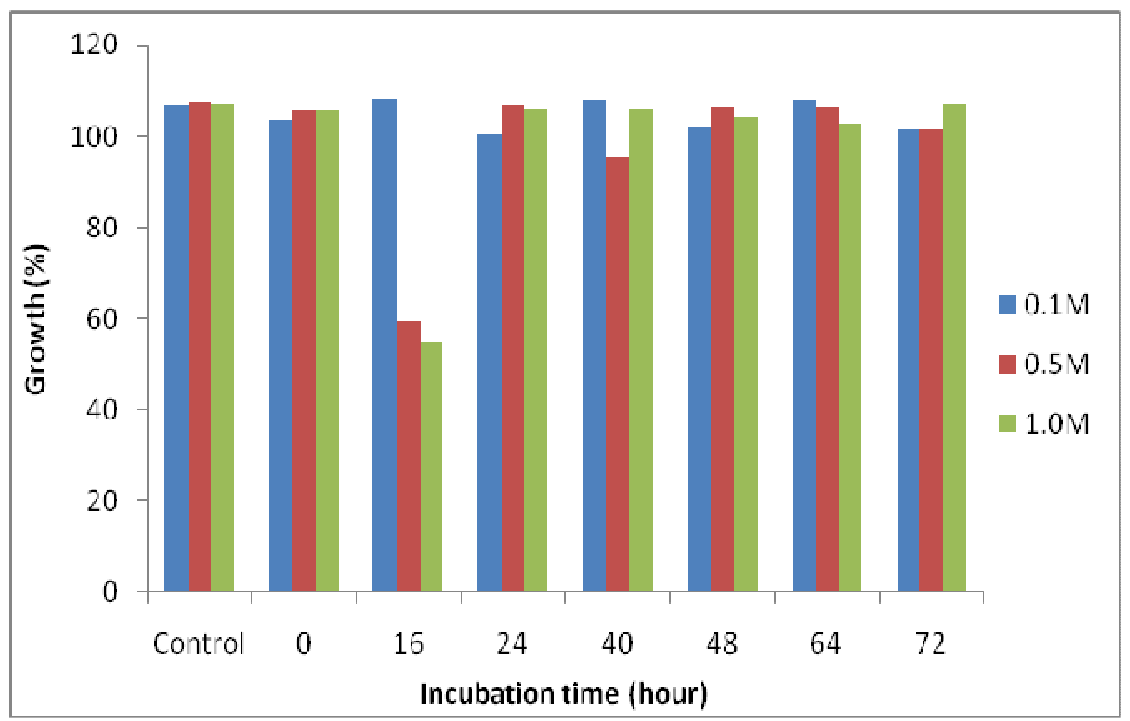

Fig. 4: Percentage of MCF-7 cells growth after treated with partially purified myoinositol phosphates from three different elution concentration of $\mathrm{HCl}$ at different incubation time.

\section{CONCLUSION}

As a conclusion, the application of partially purified rice bran myo-inositol phosphates degraded by ASUIA279 to MCF-7 breast cancer cells exhibit positive results towards the inhibition of cancer cells growth with more than $40 \%$. Therefore, through this research findings, a promising value-added product can be obtained from low cost and easily available raw material, rice bran, via hydrolysis reaction by phytase.

\section{ACKNOWLEDGEMENTS}

This research work is funded by Sciencefund research project (SF 0106-03), Ministry of Science, Technology and Innovation (MOSTI), Malaysia. Special thanks to SIRIM Berhad for providing samples as well as to all who had contributed directly or indirectly in this research.

\section{REFERENCES}

[1] A. M. Shamsuddin, "Metabolism and cellular functions of IP6: A review", 
Anticancer Res, vol. 19, pp. 3733 - 3736, 1999.

[2] R. Greiner, A. Farouk, N.G. Carlsson and U. Konietzny, "Myo-inositol phosphate isomers generated by the action of a phytase from a Malaysian waste-water bacterium", Protein J. DOI: 10.1007/s10930-007-9100-5, 2007.

[3] T. Hayakawa, K. Suzuki, H. Miura, T. Ohno and I. Igaue, "Myo-inositol Polyphosphate Intermediates in the Dephosphorylation of Phytic Acid by Acid Phosphatase with Phytase Activity from Rice Bran”, Agric. Biol. Chem., vol. 54 (2), pp. 279-286, 1990.

[4] M. Wyss, R. Brugger, A. Kronenberger, R. Remy, R. Fimbel, G. Oesterhelt, M. Lehmann, and L. APGM. Van, "Biochemical Characterization of Fungal Phytases (myo-inositol hexakisphosphate phosphohydrolases: Catalytic Properties", Appl. Environ Mirobiol, vol. 65, pp. 367-373, 1999.

[5] J. R. Loeb, N. J. Morris and F. G. Dollear, "Rice bran oil. IV. Storage of the bran as it affects hydrolysis of the oil", The Journal of The American Oil Chemists' Society, pp. 738 743, 1949.

[6] M. C. Kik and R. R. Williams, Bull. Nat.Res. Council., vol. 112, pp. 30-36, 1945.

[7] P. V. Rao, K. Jayaraman, and C. M. Lakshmanan, "Production of lipase by Candida rugosa in solid-state fermentation. 1: Determination of significant process variables", Process Biochem., vol. 28, pp. 385-389, 1993a.

[8] Y. Tani, V. Vongsuvanlert, and J. Kumnuanta, "Raw cassava starch-digestive glucoamylase of Aspergillus sp. N-2 isolated from cassava chips", J. Ferment. Technol., vol. 64, pp. 405410, 1986.

[9] H. K. Manonmani and R. Joseph, "Purification and properties of an extracellular proteinase by Trichoderma koningii",Enzyme Microb. Technol., vol. 15, pp. 624-628, 1993.

[10] A. Sumantha, P. Deepa, C. Sandhya, G. Szakacs, C. R. Soccol and A. Pandey, "Rice bran as a substrate for proteolytic enzyme production", Brazilian Archives of Biology and Technology, vol. 49 (5), pp. 843-851, 2006.

[11] R. Greiner, A. Farouk, M. L. Alminger and N.G. Carlsson, "The pathway of dephosphorylation of myo-inositol hexakisphosphate by phytate-degrading enzymes of different Bacillus spp.”, Can. J. Microbiol, vol. 48, pp. 986 - 994, 2002.

[12] T. Maffucci, E. Piccolo, A. Cumashi, M. Iezzi, A. M. Riley, A. Saiardi, H. Y. Godage, C. Rossi, M. Broggini, S. Iacobelli, B. V. L. Potter, P. Innocenti and M. Falasca, "Inhibition of the phosphatidylinositol 3-kinase/Akt pathway by Inositol pentakisphosphate results in antangiogenic and anti-tumour effects", Cancer Res, vol. 65, pp. 8339 - 8349, 2005.

[13] S. B. Shears, "The versatility of inositol phosphates as cellular signals", Biochim Biophys Acta, vol. 1436, pp. 49-67, 1998.

[14] A. L. Carrington, N. A. Calcutt, C. B. Ettlinger, T. Gustafsson, and D. R. Tomlinson, "Effects of treatment with myo-inositol or its 1,2,6-trisphosphate (PP56) on nerve conduction in streptozotocin-diabetes". Eur J Pharmacol, vol. 237, pp. 257 - 263, 1993.

[15] Vucenik and A. M. Shamsudin, "Cancer inhibition by inositol hexaphosphate $\left(\mathrm{IP}_{6}\right)$ and inositol : From laboratory to clinic", Journal of Nutrition, vol. 133, pp. 3778S-3784S, 2003.

[16] Anis Shobirin, M. H., Farouk, A., Greiner, R., Salleh, H. M. and Ismail, A. F. "Phytatedegrading enzymes production by Malaysian soil bacteria". World Journal of Microbiology and Biotechnology 23, 1653-1660, 2007.

[17] R. Greiner, U. Konietzny and K-D. Jany, "Purification and characterization of two phytases from Escherichia coli". Arch. Biochem. Biophys., vol. 303, pp. 107-113, 1993.

[18] J. K. Heinonen and R. J Lahti, "A New and Convenient Colorimetric Determination of Inorganic Orthophosphate and its Application to the Assay of Inorganic Pyrophosphatase", Anal Biochem, vol. 113, pp. 313-317, 1981.

[19] U. Konietzny, R. Greiner, and K-D. Jany, "Purification and characterization of a phytases from spelt", J. Food Biochem, vol. 18, pp. 165-183, 1995. 
[20] R. Greiner, K-D. Jany, and M. Larsson Alminger, "Identification and properties of myoinositol hexakisphosphate phosphohydrolyses (phytases) from barley (Hordeum vulgare)". J. Cereal. Sci., vol. 31 (2), pp. 127-139, 2000a.

[21] J. Van der Kaay and J. M. Van Haastert, "Stereospecificity of inositol hexaphosphates dephosphorylation by Paramecium phytase", Biochem. J., vol. 312, pp. 907-910, 1995.

[22] Q. C. Chen and B. W. Li, "Separation of phytic acid and other related inositol phosphates by high performance ion chromatography and its applications", Journal of Chromatography A, vol. 1018, pp. 41-52, 2003.

[23] M. Y. Noraini, M. S. Hamzah, and J. Parveen, "Degradation of phytate in rice bran by local bacteria phytase", Proceeding of ICCE-2009, Special Issue of Research Journal of Chemistry and Environment, pp. 361-365, 2009.

[24] A. M. Shamsuddin, "Inositol phosphates have novel anticancer function", J. Nutr, vol. 125, pp. 725S-732S, 1995.

[25] G.L. Deliliers, F. Servida, and N.S. Fracchiolla, "Effect of inositol hexaphosphate $\left(\mathrm{IP}_{6}\right)$ on human normal and leukaemic haematopoietic cells", Br J Haematol, v ol. 117, pp. 577587, 2002.

[26] L. Weglarz, B. Parfiniewicz, A. Orchel, and Z. Dzierzewicz, "Antiproliferative effects of inositol hexaphosphate and verapamil on human colon cancer Caco-2 and HT-29 cells", Acta Poloniae Pharm, vol. 63, pp. 443-445, 2006.

[27] A. M. Shamsuddin, I. Vucenik, and K. E. Cole, "IP 6 : a novel anticancer agent", Life Sc., vol. 61, pp. 343-354, 1997.

[28] M. Dorsey, H. Benghuzzi, M. Tucci, and Z. Cason, "Growth and cell viability of estradiol and $\mathrm{IP}_{6}$ treated Hep-2 laryngeal carcinoma cells", Biomed Sci Instrum, vol. 41, pp. 205-210, 2005.

[29] S. Ferry, M. Matsuda, H. Yoshida, and M. Hirata, "Inositol hexakisphosphate blocks tumor cell growth by activating apoptotic machinery as well as by inhibiting the Akt/NFkappaBmediated cell survival pathway", Carcinogenesis, vol. 23, pp. 2031-2041, 2002. [Erratum appears in Carcinogenesis. 2003 Jan; 24(1): 149].

[30] X. Zi, R.P. Singh, and R. Agarwal, "Impairment of erbB1 receptor and fluid-phase endocytosis and associated mitogenic signaling by inositol hexaphosphate in human prostate carcinoma DU145 cells", Carcinogenesis, vol. 21, pp. 2225-2235, 2000.

[31] I. Vucenic, A. Passaniti, M. I. Vitolo, K. Tantivejkul, P. Eggleton and A. M. Shamsuddin, "Anti-angiogenic activity of Inositol Hexaphosphate (IP 6 )", Carcinogenesis, vol. 25 (10), pp. $1-9,2004$.

[32] B. McMillan, D.R. Riggs, B.J. Jackson, C. Cunningham, and D.W. McFadden, "Dietary influence on pancreatic cancer growth by catechin and inositol hexaphosphate", J Surg Res, vol. 141, pp. 115-119, 2007.

[33] I. Rizvi, D.R. Riggs, B.J. Jackson, A. Ng, C. Cunningham, and D.W. McFadden, "Inositol hexaphosphate $\left(\mathrm{IP}_{6}\right)$ inhibits cellular proliferation in melanoma", J Surg Res, vol. 133, pp. 36, 2006.

[34] A. Adachi, Y. Yatani, and T. Okano, "Utilization of rice bran to prevent bulking in the activated sludge process". Journal of Health Sciences, vol. 51 (5), pp. 549-556, 2005.

[35] A. Matejuk and A. Shamsuddin, "IP ${ }_{6}$ in cancer therapy : Past, present and future", Current Cancer Therapy Reviews, vol. 6 (1), pp. 1-12, 2010.

[36] A.M. Shamsuddin and I. Vucenik, "IP 6 \& inositol in cancer prevention and therapy", Current Cancer Therapy Reviews, vol. 1, pp. 259-269, 2005. 